\title{
The use of ultrasound guided combined peripheral nerve blocks in a high-risk patient: A case report
}

\author{
Yüksek riskli hastada ultrason rehberliğinde kombine periferik sinir bloğu: Olgu sunumu
}

\author{
(D) Ali Sait KAVAKLI, (D) Nilgün KAVRUT ÖZTÜRK, (D) Ülkü ARSLAN, (D) Ferhat ENGiNAR, (D) Şenay CANIM, \\ (D) Erdinç UZUNAY
}

\begin{abstract}
Summary
Combined peripheral nerve blocks can be used as an alternative anesthetic technique for lower limb amputations in high-risk patients. The approach may vary according to the clinical condition of the patient. Presently described is the use of a combination of peripheral nerve blocks used for above-the-knee amputation in a high-risk patient: a sciatic nerve block with an anterior approach, a femoral nerve block, and a lateral femoral cutaneous nerve block.
\end{abstract}

Keywords: Amputation; anterior approach; femoral nerve block; knee; lateral femoral cutaneous nerve block; sciatic nerve block.

\begin{abstract}
Özet
Kombine periferik sinir blokları, yüksek riskli hastalarda alt ekstremite ampütasyonları için alternatif bir anestezi tekniği olarak kullanılabilir. Hastanın klinik durumuna bağlı olarak blok uygulamaları için farklı yaklaşımlar tercih edilebilmektedir. Bu olgu sunumunda, yüksek riskli bir hastada diz üstü amputasyonu sırasında anterior yaklaşım ile siyatik sinir bloğu, femoral sinir bloğu ve lateral femoral kutanöz sinir bloklarından oluşan periferik sinir bloğu kombinasyonunun kullanımı bildirilmektedir.

Anahtar sözcükler: Amputasyon; anterior yaklaşım; femoral sinir bloğu; diz; lateral femoral kutanöz sinir bloğu; siyatik sinir bloğu.
\end{abstract}

\section{Introduction}

Combination of femoral nerve block (FNB) and sciatic nerve block (SNB) was previously reported as an alternative anesthetic technique for lower limb amputations with high-risk patients. ${ }^{[1]}$ However the use of anterior approach to combined nerve block for above knee amputation in the literature is rarely. Use of posterior approach to SNB may be limited in patients with obesity, severe arthritis, trauma or severe pulmonary disease, because of the necessity of patient repositioning. Anterior approach to SNB can be used in these situations because it is performed with patient in supine position and it can be performed as easily and successfully as the posterior approach under ultrasound guidance. ${ }^{[2]}$ We report here the case of a high-risk patient in performed combined anterior approach to SNB, FNB and lateral femoral cutaneous nerve block for above knee amputation.

\section{Case Report}

A 68-year-old female patient presented with pain in left leg due to diabetes mellitus. His weight was $87 \mathrm{~kg}$, height $155 \mathrm{~cm}$ and American Society of Anesthesiologists physical status IV. There was necrosis in the $1^{\text {st }}, 2^{\text {nd }}$, and $3^{\text {rd }}$ toes of the patient and a wound with signs of infection in the anterior region. Furthermore, the wound infection was spreading upward until the knee joint. Her past medical history included congestive heart failure and chronic obstructive pulmonary disease. She suffered from orthopnea. Therefore, she was not able to lie supine and, she required the use oxygen at home. In addition, she had a history of hypertension and dyslipidemia. Electrocardiogram revealed normal sinus rhythm. Transthoracic echocardiography indicated dilatation of the left and right atriums, moderate dilation of the left ventricle with hypokinesia of septum and the other walls, left ven- 
tricular concentric hypertrophy, systolic dysfunction of the left ventricle, left ventricular ejection fraction of $20 \%$, severe mitral and tricuspid valve regurgitation, moderate aortic valve regurgitation and moderate aortic valve stenosis. For these reasons, it was decided to perform urgent above-knee amputation under regional anesthesia. Informed written consent was obtained from the patient.

Because the patient was not able to lie supine she was positioned in a semi-upright sitting position (approximately 60 degrees). Oxygen was delivered via face mask. Fatty tissue hanging from the abdomen was taped cephalad. A linear transducer (7L4A, Mindray, Shenzhen, China) was placed transversely on the inguinal crease to identify the femoral artery and nerve. A 100-mm, 20-gauge short-bevel insulated stimulating needle (Stimuplex Ultra 360, B. Braun Melsungen AG, Germany) with a nerve stimulator (Stimuplex HNS nerve stimulator, Braun, Melsungen, Germany) was used for FNB. The nerve stimulator was initially set-up to deliver a current of $2.0 \mathrm{~mA}$. At a depth of approximately $5 \mathrm{~cm}$, contractions of vastus medialis, vastus intermedialis and vastus lateralis were observed. The needle was repositioned as needed to reach muscle twitching by $0.5 \mathrm{~mA}$ current. Following negative aspiration for blood, a mixture of $15 \mathrm{ml}$ of $0.5 \%$ bupivacaine and $5 \mathrm{ml}$ of $1 \%$ lidocaine was injected for FNB. Then, transducer was positioned on the inferior to the anterior superior iliac spine for lateral femoral cutaneous nerve block. $10 \mathrm{ml}$ of $5 \%$ bupivacaine was injected the plane between sartorius muscle and tensor fasciae latae muscle. For SNB, A low frequency (5 to $2 \mathrm{MHz}$ ) curved-array transducer (C5-2, Mindray, Shenzhen, China) was transversely placed approximately $8 \mathrm{~cm}$ caudally to the inguinal crease. But a good view was not obtained. The transducer was turned longitudinally and placed over the medial side of the upper mid-thigh and between sartorius and rectus femoris muscles. And then the probe was tilted slightly medially to optimize the image. A $150-\mathrm{mm}, 20$-gauge short-bevel insulated stimulating needle (Stimuplex A, B. Braun Melsungen AG, Germany) was advanced with the current of the nerve stimulator was increased to $5 \mathrm{~mA}$. Within a depth of approximately $13 \mathrm{~cm}$, plantar flexion of the foot was observed. The current was gradually decreased to $0.5 \mathrm{~mA}$, needle orientation was optimized and a mixture of $15 \mathrm{ml}$ of $0.5 \%$ bupivacaine with $10 \mathrm{ml}$ of $1 \%$ lidocaine was injected for the SNB. 30 minutes after the blocks, sensorial blockade confirmed on the dermatomes corresponding to the femoral and sciatic nerves. During the incision of the medial thigh, the patient complained a little of pain. $100 \mathrm{mcg}$ of IV fentanyl was administered. The surgery was lasted for 70 minutes uneventfully.

\section{Discussion}

In the anterior approach to SNB which had been first described by Beck, ${ }^{[3]}$ because the sciatic nerve is located deeper than the posterior approach, it may be difficult to locate and access the sciatic nerve especially in obese patients. However anterior approach has some advantages. It is performed in supine position and not needed to change the patient's position. In addition, FNB can be performed at the same time in the same region.

Because our patient was suffered from orthopnea, she was not positioned supine. Therefore, the blocks were performed in a semi-upright sitting position. Although fatty tissue hanging from the abdomen was taped cephalad to help optimized the exposure to inguinal region, it was difficult to identify the landmarks due to the patient's position and obesity. Komasawa et al. ${ }^{[4]}$ reported a case report that the skin traction improved the ease of performance of the peripheral FNB in a morbidly obese patient. Also, adipose tissue made it difficult to visualize the nerves. We preferred longitudinal approach for anterior SNB because we could not obtain a good visualization with transverse scanning. Tsui et al..$^{[5]}$ reported that identification of the sciatic nerve with the sole use of transverse scanning was usually difficult particularly obese patients, and the sciatic nerve could be more consistently visualized along its longitudinal axis than its transverse axis.

The patient complained of little pain during incision of the medial thigh, which might be due to not blockade of the obturator nerve. Karm et al. ${ }^{[6]}$ reported in a case report about above knee amputation that similar painful responses was observed and they state that the reason for this pain was incomplete blocking of the posterior branch of the obturator nerve. However, in our patient, the pain was managed with the low dose opioid.

In conclusion, in based on our anecdotal experience, we believe that above knee amputations can be successfully done under combined peripheral 
nerve blocks in high-risk patients. In addition, anterior approach can be preffered instead of traditional approaches to SNB in patients who cannot be positioned appropriately.

\section{Funding: Departmental resources were used.}

Conflict-of-interest issues regarding the authorship or article: None declared.

\section{Peer-rewiew: Externally peer-reviewed.}

\section{References}

1. Kocum A, Turkoz A, Bozdogan N, Caliskan E, Eker EH, Arslan G. Femoral and sciatic nerve block with $0.25 \%$ bupivacaine for surgical management of diabetic foot syndrome: an anesthetic technique for high-risk patients with diabetic nephropathy. J Clin Anesth 2010;22(5):363-6. [CrossRef]

2. Ota J, Sakura S, Hara K, Saito Y. Ultrasound-guided anterior approach to sciatic nerve block: a comparison with the posterior approach. Anesth Analg 2009;108(2):660-5.

3. Beck GP. Anterior approach to sciatic nerve block. Anesthesiology 1963;24:222-4. [CrossRef]

4. Komasawa N, Watanabe N, Sakai M, Minami T. A novel skin traction method to facilitate ultrasound-guided femoral nerve block in morbidly obese patients. J Clin Anesth 2017;39:3. [CrossRef]

5. Tsui BC, Ozelsel TJ. Ultrasound-guided anterior sciatic nerve block using a longitudinal approach: "expanding the view". Reg Anesth Pain Med 2008;33(3):275-6. [CrossRef]

6. Karm MH, Lee S, Yoon SH, Lee S, Koh W. A case report: the use of ultrasound guided peripheral nerve block during above knee amputation in a severely cardiovascular compromised patient who required continuous anticoagulation. Medicine (Baltimore) 2018;97(9):e9374. [CrossRef] 